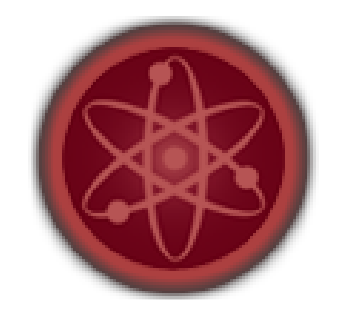

\title{
JOURNAL.RU
}

\author{
Ермаков А. С. ${ }^{1}$, Ермаков Д. С. ${ }^{2}$ \\ ${ }^{1}$ Институт экспериментальной медицины РАМН \\ Санкт-Петербург, Россия \\ ${ }^{2}$ Московский институт открытого образования \\ Москва, Россия
}

doi: 10.18411/1j2016-2-07

\section{Дефиниционные критерии наукоёмких технологий}

В 1911 г. Й. Шумпетер показал, что инновации являются основным фактором обеспечения стабильного экономического роста и дал довольно широкое определение инновациям как новым достижениям науки, техники, новым продуктам и услугам, рынкам и методам управления. Один из доминирующих подходов к формированию инновационной экономики XXI века основан на приоритетном развитии наукоёмких и высокотехнологичных отраслей за счёт перераспределения финансовых, природных и трудовых ресурсов, которые до этого использовались для производства товаров и услуг повседневного спроса (Лаптев А. А., 2007). В основе инноваций лежит использование высоких технологий и высококвалифицированной рабочей силы (Lall S., 2001). Развитие высоких технологий придаёт экономике динамизм, способствует появлению новых конкурентных преимуществ (Pyke F., Sengenberger W., 1992).

Высокие, или наукоёмкие технологии (high technology, high tech, хай-тек), - технологии, находящихся на переднем крае научных исследований, для создания и развития которых требуется персонал высшей квалификации. Данное 
понятие (high technology) начинает употребляться в англоязычной литературе с конца 1960-х гг. (Metz R, 1969). В отечественной практике ведущие технологии часто обозначают как ключевые, или критические.

Известен ряд критериев отнесения технологий, отраслей и компаний к категории наукоёмких / высокотехнологичных.

1. Уровень наукоёмкости. К категории высокотехнологичной принято относить такую продукцию, при производстве которой доля затрат на научноисследовательские и опытно-конструкторские работы (НИОКР, англ. research and development, R\&D), направленных на получение новых знаний и их практическое применение при создании нового изделия или технологии, отнесённая к результатам производства, составляет не менее 3,5 \%. В случае, если эта доля больше 8,5 \%, данное производство признаётся ведущей (leading) наукоёмкой технологией. Уровень наукоёмкости технологий среднего уровня $2,5 \%$, низкого - 0,5 \%. Следует отметить, что эти значения не являются строгими и общепринятыми (Бендиков М. А., Фролов И. Э., 2006; Вовченко В. В., 2005; Семенова Е. А., 2005).

2. Наукоотдача - отношение объёма продаж наукоёмкой продукции к расходам на НИОКР за определённый период времени (как правило, год).

3. Доля занятых в сфере НИОКР в данной отрасли по отношению к совокупной занятости в отрасли в целом (Florida R., 2002).

4. Индекс высоких технологий (Milken Institute, 1999) - доля продукции высокотехнологичных предприятий региона от общенационального производства в этих отраслях либо доля высокотехнологичных компаний в валовом региональном продукте по отношению к доле высокотехнологичных производств в валовом внутреннем продукте.

5. Группы высокотехнологичных отраслей и производств формируются, исходя из ориентации данных отраслей на коммерциализацию результатов НИОКР, а также государственное значение. Известны классификации Национального научного фонда (США), Организации Объединённых Наций (в 
рамках Стандартной международной торговой классификации) и др. По обобщённым данным (WTO, 2002) производство наукоемкой продукции в мире обеспечивают всего около 50 макротехнологий (макротехнологии представляют собой совокупность знаний и производственных возможностей для выпуска на рынок конкретных наукоёмких изделий - самолётов, космических аппаратов, конструкционных материалов, программного обеспечения и т.д.). Для Российской Федерации, в частности, выделяются (Воронин Ю. М., 2003): наноэлектроника, генная инженерия, мультимедийные интерактивные информационные системы, высокотемпературная сверхпроводимость, космическая техника, тонкая химия и пр. Указом Президента Российской Федерации от 07.07.2011 г. № 899 утверждён перечень из 27 критических технологий. 